IJOLTL, Vol. 2, No. 2, May 2017

p ISSN: 2502 2326; e ISSN: 2502 8278

Http://ijoltl.pusatbahasa.or.id; Email: ijolt1@gmail.com

Center of Language and Culture Studies, Surakarta, Indonesia

Lanua, Maretin Ardila, Rhian; Saddhono, Kundharu, \& Supana. 2017. Pshychoanalysis of Characters and Moral Values in the Novel Kepanggang Wirang (Burned Above the Shame) by Tiwik SA. IJOLTL (2017), 2(2): 65 82.

\title{
PSYCHOALYSIS OF CHARACTERS AND MORAL VALUES IN THE NOVEL KEPANGGANG WIRANG (BURNED ABOVE THE SHAME) BY TIWIEK SA
}

\author{
Rhian Ardila Maretin Lanua ${ }^{1}$ \\ Kundharu Saddhono ${ }^{2} \&$ Supana $^{3}$ \\ ${ }^{1}$ Thesis Supervisee \\ ${ }^{2 \& 3}$ Thesis Supervisors
}

Graduate Program of Javanese Education, Sebelas Maret University

Jl. Ir. Sutami 36A Kentingan, Surakarta, Central Java, Indonesia

Email: adriellryo@gmail.com; kundharu@uns.ac.id \& supana77@yahoo.com

\begin{abstract}
This study describes characters and moral values in the Javanese Novel entitled Kepanggang Wirang (Burned Above the Shame) by Tiwiek SA. Description dealt with psycholiguical needs in accordance with Abraham Maslow theory and educational values. This study is qualittaive research and applied psychoanalysis as the research design. Data were collected using contant analysis and interview and were analyzed using content analysis that included: taxonomy, domain, and thematic analyses. The study revealed that psychological needs from Maslow including: sex, security, self-esteem, and love and affection, and self-actualization were present in the novel. In addition, moral values having positive and negative perspectives were conveyed in the novel reflecting experiences in the society the readers should have considered in the real community lifes.
\end{abstract}

Keywords: moral values, psychologial needs, novel.

Received: 10 December, 2016; Accepted: 4 February 2017

\section{INTRODUCTION}

Literature as one of the forms of culture is the result of the author'creativity for lovers of literature. Literary works are created to be enjoyed, understood, and utilized by community and the author himself as a social creation. Literary works use language as a medium. Aras (2015) states literary blended fields such as history, philosophy, sociology, psychology and so on, is a discipline in which the language is used as a medium of expression so as to interpret human existence and culture. In other wors, literary work is a manifestation of creativity of the authors who combine fields such as history, philosophy, sociology, psychology who use language as a medium.

Apart from that, the birth of a literary work is the result of expression of the soul of a writer of what he experienced. According to Budianta (2006:19) the purpose of 
IJOLTL, Vol. 2, No. 2, May 2017

p ISSN: 2502 2326; e ISSN: 2502 8278

Http://ijolt1.pusatbahasa.or.id; Email: ijolt1@gmail.com

Center of Language and Culture Studies, Surakarta, Indonesia

Lanua, Maretin Ardila, Rhian; Saddhono, Kundharu, \& Supana. 2017. Pshychoanalysis of Characters and Moral Values in the Novel Kepanggang Wirang (Burned Above the Shame) by Tiwik SA. IJOLTL (2017), 2(2): 65 82.

creation of literary works is to entertaining by creating beauty, giving meaning to life (anger, misery, and excitement), or providing a release to the world of imagination.

Based on the variety, literary works consist of prose, poetry and drama. According to Budianta (2006:16) most basic genre of literary texts are of three: prose, poetry, and drama each of which is imaginary work. An imaginary work or a fiction offers a variety of human problems and of humanity, life and living. Author appreciates these issues with great seriousness and through the means of fiction he expressed in accordance with his views (Nurgiyantoro, 2010:2). Fictions include serial fiction, novels, poetry collections, short story anthology.

The novel is a prose fiction that always offers a variety of human problems that has a special attraction because it contains story of human life and elements of aesthetic. In working on a novel, the authors appreciate the variety of human problems earnestly then expressed again through a series of words in accordance with their views. To this end, novel can be enjoyed not only based on the literary appreciation but also through psychoanalysis where characters and values in the novel are aspired in adherence to the social life practices.

Psychology is literally the life science or the study of psychiatric symptoms. Psychology in the beginning was the knowledge of the human soul (Nina \& Ida, 2009:13). The study of literary psychology can be seen through psychological aspects of characters that exist in the literature. Endraswara (2003:97) mentions literature and psychology has a strong linkage, as well as indirect and functional. In indirect linkage, for both literary and psychology have the same object, namely human life. Psychology and literature have a functional relationship as it is equally useful for studying the state of one's soul. The difference is, psychiatric symptoms in a literary work is imaginary, whereas psychiatric symptoms in psychology is real psychiatric symptoms.

This study examines characters and values through psychoanalysis a novel entitled Kepanggang Wirang (Burned above the Shame) by Tiwiek SA. It is a Javanese novel that is popular in Javanese community and published in Javanese magazine for the first time prior to its sales in bookstores.

The novel was published in 2016. The novel tells that Wirastri, wife of Joni Kismanto was a victim of divorce because the husband remarried ex-girlfriend in high school. Joni Kismanto was confused to find the way to divorce Wirastri because no reasons that led to divorce. Finally, Joni Kismanto did a manipulation trick asking his friend to sleep with Wirastri. Wirastri was made to be drunk and put to sleep in the bedroom with Kismanto's friend. Wirastri was naked sleeping beside the man.

How characters and moral values in the novel is indicated by the pride and shame of the protagonist characters that involve understanding on psychological aspects of the characters. One of values that is relevant to the context is theory of Abraham Maslow on human needs. Therefore, the focus of the study is formulated as follows: 1. How are psychiatric aspect figures of characters in the novel Kepanggang Wirang based on Abraham Maslow's theory requirements? 
IJOLTL, Vol. 2, No. 2, May 2017

p ISSN: 2502 2326; e ISSN: 2502 8278

Http://ijoltl.pusatbahasa.or.id; Email: ijolt1@gmail.com

Center of Language and Culture Studies, Surakarta, Indonesia

Lanua, Maretin Ardila, Rhian; Saddhono, Kundharu, \& Supana. 2017. Pshychoanalysis of Characters and Moral Values in the Novel Kepanggang Wirang (Burned Above the Shame) by Tiwik SA. IJOLTL (2017), 2(2): 65 82.

2. How are descriptions of educational values in the novel Kepanggang Wirang work Tiwiek SA?

\section{REVIEW OF LITERATURE}

\subsection{Definition of Literary Psychology}

Literary psychology is a model of interdisciplinary research by establishing literature as having a more dominant position (Ratna, 2004:349). Basically literary psychology gives attention to the discussion in relation to elements of psychological fictional characters contained in literature. Psychology is science that deals with mental processes of normal and abnormal influence on the behavior or knowledge about symptoms and activities of people.

According to Ratna (2001:340) literary psychology is analyzed in relation to psychosocial, psychological aspects of the author (2001: 340). Literary psychology has four possible senses: author as a person indicating, psychology as creative process, the laws of psychology as applied to literary works, and the study of impact of literature on the reader (reader psychology) (Wellek and Weren, 1989:90). In contrast, Scott in Endraswara (1989:69-70) identifies research of literary psychology includes three possibilities: 1) accidental relationship between author and reader, 2) the study of the life of the author to understand his work, 3) the study of character of the characters in the literary work.

The purpose of literary psychology is to understand psychological aspects contained in a literary work (Ratna, 2014:342). Nevertheless, it does not mean that a psychological analysis of literature at all apart with community needs. In accordance with the essence, literature gives an understanding of the society indirectly. Through an understanding of the characters, for example, public can understand the changes, contradictions, and other irregularities that occur in society, particularly in relation to the psyche.

Literary work that is seen as a psychological phenomenon, will feature aspects of psychiatric through figures if by chance the text takes the forms of drama and prose, whereas if it is a poem it would appear through the array and choice of typical words (Endraswara, 2003:96). Similarly Jatman (in Endraswara, 2003:97) argues literature and psychology does have a close linkage, indirect and functional. Indirectly, both literary and psychology have the same object, namely human life. Psychology and literature have a functional relationship as equally to study people's psychological state. The difference is psychiatric symptoms in a literary work is imaginary, whereas psychiatric symptoms in psychiatric psychology is real.

Basically, literary psychology is supported by three approaches: 1) textual approach, which examines psychology of characters in works of literature; 2) receptivepragmatic approach, which examines psychological aspects of reader as a connoisseur of literature in the form of influence of the works he had read, and enjoy process of reception reader in literary works; 3) expressive approach, which examines 
IJOLTL, Vol. 2, No. 2, May 2017

p ISSN: 2502 2326; e ISSN: 2502 8278

Http://ijoltl.pusatbahasa.or.id; Email: ijolt1@gmail.com

Center of Language and Culture Studies, Surakarta, Indonesia

Lanua, Maretin Ardila, Rhian; Saddhono, Kundharu, \& Supana. 2017. Pshychoanalysis of Characters and Moral Values in the Novel Kepanggang Wirang (Burned Above the Shame) by Tiwik SA. IJOLTL (2017), 2(2): 65 82.

psychological aspects of the author when projecting creative process through his work, both as a writer of personal and community representatives (Roekhan in Endraswara, 2003:97).

Literary psychological research does have a solid foundation. It is because, literature and psychology have the same object that is the study of human life. Distinction appears in that literary studies humans as creatures of imagination of the author, while psychology focuses on a divine creation in real terms (Endraswara, 2003:99). Based on the above exposure can be synthesized that psychology is the study of literary works as mental activity. Psychology has a crucial focus of analysis on literary work from the point of mental literary works in terms of elements of the authors, characters, and readers.

\subsubsection{Focus of Literary Psychology Research}

Focus of psychology literature research should be on the goal, emphasizing on character psychology or process of creativity of the author. This way, researcher can keep it on the focus of research. Steps and processes begins on psychology research target figuring number of characters as the following. First, psychology literature approach emphasizes on overall assessment of intrinsic or extrinsic elements, focusing on intrinsic elements, i.e. characterizations and actors. Second, figure and character should be complimentary to issue theme. Analysis of figures should be emphasized in logics of character behavior. People who highlighted should focus not only on the main characters, both the protagonist and antagonist, but also other important figures. Third, conflict of character among actors is associated with the storyline. These figures should be associated with structurally storyline. The structure of the work should remain the grip from beginning to end of the study to avoid that researchers do not get stuck on the use of psychological theory (Endraswara, 2003:104).

If the goal of the research is on creativity aspect, the steps are: first, extrinsic aspects need to be discussed, which includes the ideals, aspirations, desires, philosophy of life, obsession, and personal demands. In this regard, it should be sought biographical writer since childhood to adulthood. In this way it will be known deposition personal experience expressed in his work. Second, process of creation needs to be explored, e.g. motives of creation. Third, researchers can also associate with the psychological impact of the work (Endraswara, 2003:105).

\subsubsection{Theory of Psychology of Abraham Maslow}

Abraham Maslow a pioneer of humanistic psychology states that a mankind as a whole should be seen as a unique process, which contains all aspects of himself and the process to be himself (self-actualization). Wortman, et. all (2004:18) states: 
IJOLTL, Vol. 2, No. 2, May 2017

p ISSN: 2502 2326; e ISSN: 2502 8278

Http://ijoltl.pusatbahasa.or.id; Email: ijolt1@gmail.com

Center of Language and Culture Studies, Surakarta, Indonesia

Lanua, Maretin Ardila, Rhian; Saddhono, Kundharu, \& Supana. 2017. Pshychoanalysis of Characters and Moral Values in the Novel Kepanggang Wirang (Burned Above the Shame) by Tiwik SA. IJOLTL (2017), 2(2): 65 82.

Humanistic psychology emphasized the importance of conscious, rather than unconscious, motivations for behavior. Grounded in the ideas of free will and choice, it was directly opposed to the more rigid determinism of psychoanalysis. Humanistic psychologist also stressed the positive aspects of psychological development, emphasizing the basic good in people.

In sum, humanistic emphasizes the importance of awareness, rather than unconscious. All of it is based on the ideas of free will and choice. Humanistic psychology also emphasized positive aspects of psychological development, which emphasizes the good basic foundation of people.

Sarwono (2010:33) states the purpose of humanistic psychology is to encourage good potentials of a person to the process of actualizing. Maslow's theory is also known as the theory of motivation hierarchy or hierarchy of need. Humans have various needs to meet ranging from lowest to the highest. If the lowest needs are fulfilled, there would appear higher needs. Idemobi (2011:169) argue when one need is satisfied, another higher-level need emerges and motivates the person to do something to satisfy it. That means if one need is satisfied, other need will come and motivate people to meet those needs. Five needs according to Maslow (1994:43) includes: (1) the physiological needs, (2) need for security, (3) need for love and belonging, (4) need for self-esteem, (5) need for self-realization (self-actualization).

\section{a. Physiological Needs}

Physiological needs are the most important needs and most powerful. Physiological needs are human needs in order to sustain life, namely the need for air, food, water, shelter, sex, and sleep (Globe, 1987:71).

Physiological needs are basic needs that must be met humans. If human beings are not able to meet basic needs then people will lose himself. Conversely, if these needs have been satisfied, it will appear new needs that are higher. Therefore, the physiological needs influence other needs. The physiological needs, when unsatisfied, dominate the organism, pushing all capacities into service and organizing. If physiological needs are not met it will encourage all capabilities to fulfill these needs.

\section{b. The need for security}

The need for security is a necessity to these two levels after physiological needs. The need for security relates to the safety (security), steadiness, dependability, protection, freedom from fear, anxiety and confusion, order, law, the limits, the power of the self-protective, etc. (Maslow, 1994:47).

\section{c. Needs for sense of being loved and belonging}

If physiological and safety needs are met it will appear the third requirement, need for a sense of belonging and love. Everyone needs a loving relationship with 
IJOLTL, Vol. 2, No. 2, May 2017

p ISSN: 2502 2326; e ISSN: 2502 8278

Http://ijolt1.pusatbahasa.or.id; Email: ijolt1@gmail.com

Center of Language and Culture Studies, Surakarta, Indonesia

Lanua, Maretin Ardila, Rhian; Saddhono, Kundharu, \& Supana. 2017. Pshychoanalysis of Characters and Moral Values in the Novel Kepanggang Wirang (Burned Above the Shame) by Tiwik SA. IJOLTL (2017), 2(2): 65 82.

people in general so that he would endeavor harder to achieve goals (Maslow, 1994:53). The need for love covers love giving and receiving love. Everyone craved loving relationships with others. If these needs are met it will increase confidence.

\section{d. The need for self-esteem}

Maslow (in Golbe, 1987:76) found that each person has two categories of a need for awards, namely (a) self-esteem, including need for confidence, competence, mastery, sufficiency, achievement, independence, and freedom; (b) respect of others including prestige, recognition, acceptance, attention, status, reputation and awards. Someone having enough self-esteem will be more confident and more capable, and he will be more productive. Conversely, if the self-esteem is less he will perform low selfesteem and feelings of helplessness, which in turn can lead to despair.

\section{e. The need for self-actualization}

The need for self-actualization is the physiological need to grow, develop, and use abilities. That term refers to the desire of people to be self-realization, namely: the tendency to manifest itself within its capabilities. This trend can be expressed as a desire for more and more special, to become anything according to his ability (Maslow, 1994:57).

\subsection{Educational Values}

\subsubsection{Essence of Value}

Values are something abstract, but functionally it has feature to distinguish between one with the other. Values are traits, the things that are important and useful for life. Values are rules that determine an object or an act of a higher, required from the other (Ahmadi \& Uhbiyati, 1991:69). Values are a matter of how to determine what is valuable from the others, what is desired and what is denied. In short, value is everything about the good and bad that have properties useful to humans.

Education generally aims to help people discover the nature humanities. That is, education must embody on human beings, expecting human education to realize its potential as a thinking creature. Soedono (2003:18) explained the meaning of education is the assistance provided by the person responsible to the students in a mature business man through teaching and training undertaken.

According to Tilaar (2000:28) education is a process to develop learners who socialized existence and entrenched, in the governance dimension of life locally, nationally and globally. It is to say that education is a process to develop learners who socialized existence and entrenched, in the governance dimension of life locally, nationally and globally against the physical and spiritual development of the students towards the establishment of a major personality. 
IJOLTL, Vol. 2, No. 2, May 2017

p ISSN: 2502 2326; e ISSN: 2502 8278

Http://ijoltl.pusatbahasa.or.id; Email: ijolt1@gmail.com

Center of Language and Culture Studies, Surakarta, Indonesia

Lanua, Maretin Ardila, Rhian; Saddhono, Kundharu, \& Supana. 2017. Pshychoanalysis of Characters and Moral Values in the Novel Kepanggang Wirang (Burned Above the Shame) by Tiwik SA. IJOLTL (2017), 2(2): 65 82.

\subsubsection{The Nature of Morale}

Moral originates from the word mos (mores), which is synonymous with morality, behavior. Moral is the doctrine of good and bad, which concerns the behavior and actions of people. A person who obeys the rules, the rules and norms in society, considered appropriate and morally correct action. If the case is in an opposite, the person is considered immoral. Morale in the embodiment may include rules or principles of truth, good, commendable and noble. Morale can be loyalty, adherence to the values and norms which bind the life of society, nation and state. The norm is the embodiment of human dignity as a creature of cultural, social, moral and religious. Norma is an awareness and sublime attitude desired by the values to be obeyed.

Helden (1977) and Richard (1971) describe a moral sense as sensitivity in thoughts, feelings, and actions compared with other measures that are not only in the form of sensitivity to the principles and rules. Atkinson (1969) suggests a moral or morality is a view of good and evil, right and wrong, what can and can not do. Moral is also a set of beliefs in a society with regard to the character or behavior and what is supposed to be human.

Morality is basically the same as the moral, but morality implies all matters pertaining to the moral. Morality is a system of values about how one should live as well as humans. Morality is contained in the rules of social life in the form of advice, advice, counsel, regulations, orders, and the like that are passed from generation to generation through a particular religion or culture. If the case is in an opposite, the person is considered immoral. Morale in the embodiment may be regulatory or principles of right, both praiseworthy and noble. Morale can be loyalty, adherence to the values and norms which bind the life of society, nation and state.

\subsection{Educational and Moral Values in a Novel}

The literary work always offer moral values relating to human nature, fighting for human rights and dignity (Nurgiyantoro, 2007:232). Virtues of humanity are in fact universal. That is, the properties it owned and believed to be true by humans. Etymologically (the origin of the word) the moral comes from the word "mos" or "mores" meaning manners, customs, habits, or behavior (Sudarsono, 1985:23). Moral values in literature usually aim to educate people to recognize their aesthetic values and character.

A literary work offering moral values that are universal, is generally accepted its truth as universal and allow it to be a work that is sublime, although it is also determined by the other intrinsic elements. Moral is a very important rule enforced in a society because it can be a sign in life as well as a protector of community itself. Moral behavior is resulted from intellectual, emotional, or intuitive thinking of each individual who is ultimately accepted as a rule in life to appreciate and distinguish between right and wrong prevailing in a society. Moral values indicate rules of behavior and customs of an individual from a group that includes behavior. 
IJOLTL, Vol. 2, No. 2, May 2017

p ISSN: 2502 2326; e ISSN: 2502 8278

Http://ijoltl.pusatbahasa.or.id; Email: ijolt1@gmail.com

Center of Language and Culture Studies, Surakarta, Indonesia

Lanua, Maretin Ardila, Rhian; Saddhono, Kundharu, \& Supana. 2017. Pshychoanalysis of Characters and Moral Values in the Novel Kepanggang Wirang (Burned Above the Shame) by Tiwik SA. IJOLTL (2017), 2(2): 65 82.

\section{METHOD}

This research is a qualitative descriptive study, that produces descriptive data in the form of words written or spoken of people and observed behavior. This type of research is the study of literature, where the object of study is the literary word. By considering the literary work is an integral part of culture, the application of theory was conducted in two stages, first, the theory in literature as a product of a particular social (analysis extrinsic), the two theories in relation to literature as the nature of imagination and creativity (analysis of intrinsic) (Ratna, 2009:11). This research investigated psychology of characters and values of the novel of Kepanggang Wirang (Burned above the Shame) by Tiwiek SA. The data collected in this study is the form of words, sentences, phrases, paragraphs, and discourse that are relevant to mental health needs of figures based on the theories of Abraham Maslow. Data were collected from content analysis and interview. Data were analyzed using Flow Diagram from Miles and Huberman (1994) and elaborated into domain analysis, taxonomy analysis and thematic analysis.

\section{FINDINGS AND DISCUSSION}

\subsection{Characters Based on Maslow's Theory}

\section{Physiological Needs}

Physiological needs are the needs of the most important and most powerful. Physiological needs are human needs to sustain life: need for air, food, water, shelter, sex, and sleep (Globe, 1987:71). Physiological needs must be met by humans. If these needs can not be fulfilled, it will affect a person's psychological. Physiological needs are described in the novel of Kepanggang Wirang through behavior of the characters.

Physiological needs experienced in Wirastri figures after drinking milk that has been mixed with stimulants by Pradopo. Wirastri body felt like wanting to have sex with the opposite sex. Instantly Wirastri was moved to her bedroom. Suddenly Pradopo came as scenario by Joni Kismanto to have sex with Wirastri. See excerpt (1):

(1) "Ing kahanan kaya mangkono, dumadakan ana pawongan kumliwer. Mlebu kamar kui tanpa pepoyan. Ora dingerteni saka ngendi sangkane. Pancen ya ora ana sing kober ngerteni. Awit pinuju sepi. Ing njero omah kono mung Wirastri dhewe. Pawongan kasebut kober ngowoh weruh kahanane Wirastri. Ning mung sedhela. Sajak emoh kelangan kalodhangan, si pawongan enggal cucul panganggo. Lan kanthi semangat ajag kaliren, gagae ngrangsang. Lan, bab-bab sing mesthine ora kena dumadi, kepeksa kadadeyan!" (Tiwiek SA, 2016:34).

\section{Translation:}

In such circumstances, suddenly there was a pass. Entered the room without permission. It is not known where it came from. Did not have time to understand. 
IJOLTL, Vol. 2, No. 2, May 2017

p ISSN: 2502 2326; e ISSN: 2502 8278

Http://ijolt1.pusatbahasa.or.id; Email: ijolt1@gmail.com

Center of Language and Culture Studies, Surakarta, Indonesia

Lanua, Maretin Ardila, Rhian; Saddhono, Kundharu, \& Supana. 2017. Pshychoanalysis of Characters and Moral Values in the Novel Kepanggang Wirang (Burned Above the Shame) by Tiwik SA. IJOLTL (2017), 2(2): 65 82.

Because it deserted. Inside the house there is only Wirastri alone. The someone was surprised to see the condition Wirastri. But only briefly. Like do not want to lose the opportunity, one is immediately melapas clothes. And with the spirit immediately rushed. And, things that should not be happening, forced happen! "(Tiwiek SA, 2016:34)

The above quote shows that sexual needs experienced Wirastri after receiving stimulant drugs that was poured in the milk beverage. Instantly desire for sexual relationships arose in Wirastri. Sex desire is universal to human being as indicated by the plan of Wirastri's hueband to design a sex scandal between Wirastri and Pradopo.

\section{The Need for Security}

Safety needs are needs that arise when physiological needs are met. The need for security is essentially the need to defend themselves from the various problems that arise in life. In the novel Kepanggang Wirang, the need for security is indicated by the characters in script (2).

(2) "Cilaka! Yen tetelune ketemu neng rumah sakit genah njur ngerti sapa sing gawe cilakane. Pradopo genah njur cerita! Grenenge kanthi swara rada geter. Wirastri ngrasa rada getun. Yagene wingi nalika milara Pradopo ora nyamar. Kok krudunge dadak dicopot. Pulisi genah wis ngerti sapa pawongan manganggo ireng-ireng sing gawe cilakane pimpinan Bank Dana Arta lan bojone kui. Ngono pangirane Wirastri. Pangira sing banget tinemu nalar. Ya jalaran iku dheweke banjur ketuwuhan rasa kuwatir. Awit ora mokal pulisi wiwit nyebar telik kanggo nemokake dheweke." (Tiwiek SA, 2016: 112)

\section{Translation:}

"Rats! When the three met at the hospital certainly caught alone who make trouble. Pradopo definitely a story! grumbled voice trembling slightly. Why veil should be removed. The police must have known who the people are dressed in black who made wretched leadership of Bank Arta and his wife Dana. So Wirastri forecasts. A reasonable estimate. Yes because it suddenly appeared worry. Since it was the police began to spread the news to find her. "(Tiwiek SA, 2016: 112)

The above quotation explains that the need for security is required by everyone. If the security needs are not met, the person feel anxious and vigilant at every person. As with Wirastri after a successful revenge against Pradopo, Joni Kismanto and his wife, Wirastri worried for fear if her actions would be immediately known. To be safe, Wirastri left the town in Kediri and backed again to Bali. 
IJOLTL, Vol. 2, No. 2, May 2017

p ISSN: 2502 2326; e ISSN: 2502 8278

Http://ijoltl.pusatbahasa.or.id; Email: ijolt1@gmail.com

Center of Language and Culture Studies, Surakarta, Indonesia

Lanua, Maretin Ardila, Rhian; Saddhono, Kundharu, \& Supana. 2017. Pshychoanalysis of Characters and Moral Values in the Novel Kepanggang Wirang (Burned Above the Shame) by Tiwik SA. IJOLTL (2017), 2(2): 65 82.

\section{Needs of Loved and Affection}

Every person must have a sense of love and affection. Love and affection were born naturally to everyone. Everyone wants to love and be loved. A love that appears in a person make the person want to have something he loves. It was very humane. Love and affection can occur in the opposite sex, friends, parents and families.In the novel Kepanggang Wirang works Tiwiek SA, the need for a sense of being loved and have demonstrated by the behavior of the characters. This love includes the love of parents and the opposite sex. See excerpt (3).

(3) "Priye Pak kahanane?" pitakone Pujilestari. Bapake mlengos. Plalah mirsani papan liya. Patrap ngene iki jane ngagetake Pujilestari. Ngagetake uga nggelakake. Ning ora diketarakake. Pujilestari rewa-rewa ora krasa. Malah banjur takon maneh, "jane sapa ta Pak sing tumindhak jahat iki? Kok Bapak nganti dipilara kaya ngene. Aku ngerti yen bapak gerah, mentas iki mau merga dikandhani Mbok Nah. Ning gerahe rak ora banget-banget ta Pak. Kayane ora ana tatune." (Tiwiek SA, 2016: 124)

\section{Translation:}

"How Pak condition?" Asked Pujilestari. His father indifferent. Instead, look elsewhere. Things like this actually shocked Pujilestari. Shocked and upset. But not shown. Pujilestari pretended not to feel. In fact, then asked again, "exactly who Mr. evildoers like this? Mr Kok to be hurt like this. I know that Mr. sick, then given the same mBok Nah. But the pain is not too severe right sir. It seems that no traces. "(Tiwiek SA, 2016:124)

The above quote shows visible affection shown by Pujilestari to her father's child. Pujiestari showed affection to Joni Kismanto being hospitalized, the affection did not get enough response from Joni Kismanto, making Pujilestari disappointed. The need for a sense of being loved and affection ias also indicated by Joni Kismanto. This is evident when Joni Kismanto returned to Solo to visit her mother. In Solo Joni Kismanto got the news of his old colleague Suminingrum is a widow. Joni Kismanto then contacted Suminingrum as seen in excerpt (4).

(4) "Joni Kismanto ora sranta. Dheweke nyerak, nganti mepet. Banjur saka lesane kawetu ucap lirih, "Jeng, aku ora kabotan misah ibune bocah-bocah sen sliramu gelem dakrengkuh.” (Tiwiek SA, 2016: 28)

\section{Translation:}

"Joni Kismanto is impatient. He gets closer, to coincide. Then from his mouth came out in a low voice, "Jeng, I would not mind to divorce her children if you want me to have." (Tiwiek SA, 2016: 28) 
IJOLTL, Vol. 2, No. 2, May 2017

p ISSN: 2502 2326; e ISSN: 2502 8278

Http://ijoltl.pusatbahasa.or.id; Email: ijolt1@gmail.com

Center of Language and Culture Studies, Surakarta, Indonesia

Lanua, Maretin Ardila, Rhian; Saddhono, Kundharu, \& Supana. 2017. Pshychoanalysis of Characters and Moral Values in the Novel Kepanggang Wirang (Burned Above the Shame) by Tiwik SA. IJOLTL (2017), 2(2): 65 82.

The above quotation explains that the amount of love and affection from Joni Kismanto is against Suminingrum. Needs of being loved and affection are also available on Pujilestari to Wirastri. Pujilestari felt the loss of affection since his parents divorced. See excerpt (5).

(5) "Pujilestari nutupi raine. Banjur nangis miseg-miseg. Ing antarane tangise, dheweke kandaha, "Ngene iki aku pengin nusul Ibu! Pengin jaluk ngapura awit mbiyen melu-melu mungsuhi. Ning neng endi dununge saiki. Apa kowe ora ngerti tenan ta Mbok? Huuu... Huuu... Huuu..." (Tiwiek SA, 2016: 131)

\section{Translation:}

"Pujilestari over his face. Then the sobbing cry. On the sidelines of the crying, he said, "If you like this I want to follow Mom! Want to apologize because the first bandwagon hostile mother. But where its presence now. What you do not know the real mBok? ... .. Hooo hooo hooo ... "(Tiwiek SA, 2016: 131)

The above quotation shows that Pujilestari received lack of affection from his parents. Since her parents divorced, attitude of Joni Kismanto to Pujilestari and Dwi Saksono was very different. Joni Kismanto discriminated to his stepson from Suminingrum. This makes Pujilestari and Dwi Saksono were jealous on the discrimination.

\section{Needs of Self-Esteem}

Fulfillment create feelings of self-esteems is very important. If the need for selfesteem is not met it will cause a sense of inferiority, a sense of defeat, weak and worthless. To meet the needs of self-esteem, everyone will try hard to get it. Character in the novel Kepanggang Wirastri Wirang Tiwiek SA appears in quote (6).

(6) "Wis wayahe aku males wirang marang bajul buntung kuwi!" mangkono osiking batin. Ujug-ujug polatane kobong. Pratandha yen atine umrik." (Tiwiek SA, 2016: 80)

\section{Translation:}

"It is time for me to reply to the crocodile stump ashamed of it!" Was her inner turmoil. Suddenly emotions heated up. A sign that his anger. "(Tiwiek SA, 2016: 80)

The above quotation explains that Wirsatri strongly rejected that Pradopo underestimated her self-esteem. Wirastri feel humiliated after ravished by Pradopo. Wirastri determined to take revenge against Pradopo. 
IJOLTL, Vol. 2, No. 2, May 2017

p ISSN: 2502 2326; e ISSN: 2502 8278

Http://ijoltl.pusatbahasa.or.id; Email: ijolt1@gmail.com

Center of Language and Culture Studies, Surakarta, Indonesia

Lanua, Maretin Ardila, Rhian; Saddhono, Kundharu, \& Supana. 2017. Pshychoanalysis of Characters and Moral Values in the Novel Kepanggang Wirang (Burned Above the Shame) by Tiwik SA. IJOLTL (2017), 2(2): 65 82.

\section{Self-Actualization Needs}

Self-actualization needs arises when all the requirements are met. Need for selfactualization is the need to obtain satisfaction with by mobilizing all its capabilities and power. To obtain self-actualization needs one should strive to exert the spirit, mind, intelligence and creativity has. In the novel Kepanggang Wirang, self-actualization is seen as Wirastri was successful to revenge to Pradopo, Kismanto and Joni. She is satisfied after she made Joni Kismanto and Pradopo paralyzed as a man and Suminingrum lose her beauty. See excerpt (7).

(7) "Wirastri lega. Cumeplog banget rasane. Ilang blsas sanggane. Rumangsa mungkur saka sanggan batin sing sasuwene iki nyumpel ing dhadha. Wirange wis katebus. Kesumate wis antuk panyaluran. Pradopo, Joni Kismanto apadene Suminingrum wis ngundhuh wohing pakarti." (Tiwiek SA, 2016: 111)

\section{Translation:}

"Wirastri satisfied. Feels very satisfied. Gone was her burden. Feeling out of this mental burden during menyelmuti chest. Embarrassed been paid. Vengeance is already getting the rebound. Pradopo, Joni Kismanto or Suminigrum already got rewarded with deeds. "(Tiwiek SA, 2016: 111)

\subsection{Values of Moral Education}

Moral education contained in a literary work educates people to recognize the ethical values as value of a good and bad deeds, what to avoid, and what to do, so as to create an order of human relations in society to be considered good, compatible, and the benefit of others, environment and yourself. Riza (2005:194) said that morality is a person's ability to distinguish between good and bad.

Author of the novel Kepanggang Wirang wants to show their negative and positive moral values that can be taken on this novel. Author wants to convey a message to the reader to a person by leaving grudges and forgive the mistakes made by others. Negative moral values in this novel are often found stories of anarchy, infidelity, differences affection and also revenge that takes place in the lives of the characters. Anarchy and revenge for example found in persecuting Wirastri figures Joni Kismanto, Suminingrum and Pradopo. Wirastri committed to acts of anarchy to beat Joni Kismanto in office of Dana Arta bank as in quote (8).

(8) "Si krudhung ireng sajak tanggap. Tanpa menehi kalodhangan marang Joni kanggo muter akal licike, ujug-ujug wis mlumpat nrejang. Tandange tringkas banget. Sajak kepenak wae nglumpati meja ing ngarepe sing sabanjure nggejohake tungkake sing mawa sepatu kets iku pener dhadhane Joni. Sing kena gejoh kebanting memburi, natap tembok ruwangan. Sakala sirahe klemunklemun." (Tiwiek SA, 2016: 2) 
IJOLTL, Vol. 2, No. 2, May 2017

p ISSN: 2502 2326; e ISSN: 2502 8278

Http://ijolt1.pusatbahasa.or.id; Email: ijolt1@gmail.com

Center of Language and Culture Studies, Surakarta, Indonesia

Lanua, Maretin Ardila, Rhian; Saddhono, Kundharu, \& Supana. 2017. Pshychoanalysis of Characters and Moral Values in the Novel Kepanggang Wirang (Burned Above the Shame) by Tiwik SA. IJOLTL (2017), 2(2): 65 82.

\section{Translation:}

"The black mask understand. Without giving to Joni to play evil mind, suddenly jumped. Agile movement. As light vaulting over the table in front of him which then kicking his heels right breast exposed Joni.yang kick pushed to the back, hit the wall of the room. Instantly his head was dizzy. "(Tiwiek SA, 2016: 2)

Wirastri took revennge to Joni Kismanto because Joni manipulated incident as if Wirastri had sexual contact to Pradopo to meet Joni's trick. This way, Joni divorced Wirastri and he married to Suminingrum. In addition, Wirastri took an anarchy to Suminingrum because she thought that Suminingrum was the actor that made she was divroced by his husband.

Different love given by Joni Kismanto to their children also become one of the negative moral values inherent in novel. Love and affection from Joni to his dauther Pujiningrum and his son Dwi Saksono since he married Suminingrum decreased. Joni Kismanto gave more love to the stepdaughter of the second biological child as seen in quote (9).

(9) "Erni njegreg. Aneh banget! Mau nalika dicaketi putrane dhewe sajak kipa-kipa. Kepara nudhuhake ulat duka. Bareng saiki bisa gumyeg karo putra kuwalone. Ana apa sejatine ing kulawargane Pak Joni iki?" (Tiwiek SA, 2016: 127)

\section{Translation}

Erni kept silent. Very surprising. When his own sons closed, he refused. Expressed hate attitude. But now, he was happy to share with his stepdaugther. What actually happened with Joni's family? (Tiwiek SA, 2016:127).

There are many positive moral values in the novel Kepanggang Wirang. Positive moral values in the novel are a sense of forgiveness to life happier and more prosperous. It happened on Wirastri when returned to Java, but Mr. Made Tantra warned not to hold any grudges if we want to live in peace. See quote (10).

(10) "Aku ora bisa nyandhet pepinginanmu Ndhuk. Bisaku mung jumurung. Mung welingku, aja kokturuti bruwalmu. Ati panasmu aja kokumbar dadi kesumat. Sing uwis ya uwis, lelakon kepungkur busaken saka uripmu. Ing kono kowe bakal nemu kabagyan lan katentreman." (Tiwiek SA, 2016: 83)

\section{Translation:}

"I could not inhibit desire boy. I can only pray. It's just that my message, do not obey your emotions. Do not you let your hot heart to revenge. That is yes, then delete the events of your life. There will not be happiness and peace. "(Hereby SA, 2016: 83). 
IJOLTL, Vol. 2, No. 2, May 2017

p ISSN: 2502 2326; e ISSN: 2502 8278

Http://ijolt1.pusatbahasa.or.id; Email: ijolt1@gmail.com

Center of Language and Culture Studies, Surakarta, Indonesia

Lanua, Maretin Ardila, Rhian; Saddhono, Kundharu, \& Supana. 2017. Pshychoanalysis of Characters and Moral Values in the Novel Kepanggang Wirang (Burned Above the Shame) by Tiwik SA. IJOLTL (2017), 2(2): 65 82.

Positive moral values also appeared on caharters of Joni Kismanto and Suminingrum. To keep chastity and self-esteem is very important for a woman. The love of Suminingrum to Jini Kismanto has made she renderred her virginity, but Joni Kismanto rejected the offer of Suminingrum. See quote (11).

(11) "Aja Jeng! Aja tenan! Kuwi dosa gedhe! Aku percaya Jeng Sumi nresnani aku lair batin. Aku percaya tresnane Jeng Sumi suci. Mulane ora perlu dikotori kanthi tumindhak nyimpang saka wawaler. Kesucenmu kudu kokpasrahake marang garwamu." (Tiwiek SA, 2016: 19)

\section{Translation:}

"No. Don't do it! Seriously do not! It's a great sin! I believe mistress Sumi loves me spiritually. I believe in love mistress Sumi holy. So do not get smudged by doing things that deviate from the norm. Purity should you give to your husband. "(Hereby SA, 2016: 19)

Honoring parents is one of the positive moral values that the author wants to convey to the reader. Author delivered the message to the reader through Suminingrum describing a child has to be obedient to their parents. Excerpt (12) is the example.

(12) “...aku mung bocah wadon Mas. Kathik wiwit cilik wis digladhi mbangun miturut marang wong tuwa. Rasane ora mentala lan ngrasa dosa arep mbangkang kersane wong tuwa. Mula apuranen aku dene kepeksa mblenjani janji ora sida urip bebarengan karo sliramu." (Tiwiek SA, 2016: 17)

\section{Translation:}

"... I'm just a girl Mas. Since little has been taught to respect the elderly. It does not seem bold and feel guilty if they want against the wishes of parents. So forgive me not be forced to renege on a promise to live together with you. "(Tiwiek SA, 2016: 17)

Having an optimistic spirit in ourselves to realize something is also a positive moral value contained in Kepanggang Wirang. Through Joni Kismanto figures, the authors conveyed positive moral message to the readers to always have an optimistic spirit in reaching a goal. See excerpt (13).

(13) "Wurung mengku Suminingrum, nylomot semangate kanggo tumemen anggone kuliyah. Joni ngira, anggone ora sida kepilih dadi mantune Pak Bei Abdullah Sasrogondho, jalaran dheweke dudu trah ningrat. Hla kanggo nebus iki dheweke kudu kasil kuliyahe. Sarjana ekonomi kudu kecekel tangan lan sawise iku kudu 
IJOLTL, Vol. 2, No. 2, May 2017

p ISSN: 2502 2326; e ISSN: 2502 8278

Http://ijoltl.pusatbahasa.or.id; Email: ijolt1@gmail.com

Center of Language and Culture Studies, Surakarta, Indonesia

Lanua, Maretin Ardila, Rhian; Saddhono, Kundharu, \& Supana. 2017. Pshychoanalysis of Characters and Moral Values in the Novel Kepanggang Wirang (Burned Above the Shame) by Tiwik SA. IJOLTL (2017), 2(2): 65 82.

kecekel gawe sing bisa ngangkat drajate sababag karo kaum ningrat." (Tiwiek SA, 2016: 18)

\section{Translation:}

"Failed to marry Suminingrum, create his enthusiasm for studying in earnest. Joni thought, he failed to be elected into law Abdullah Pak Bei Sosrogondho because he was not highborn. To make up for it all he had to succeed in college. Economics graduate must successfully achieved and then should get a job that could raise the equivalent rank of the nobles. "(Hereby SA, 2016: 18)

Author through the novel wanted to convey moral lessons to the reader to educate better life. Respect for elders, having a spirit of optimism in achieving something, keeping chastity are of positive moral values conveyed by the author to the readers. Similarly, the negative moral values are also given by the author to readers in terms of not to do things that are anarchists and do not have a grudge against someone else. Based on the above analysis it can be concluded that there are positive and negative moral values in the novel of Kepanggang Wirang by Tiwiek SA. Author through literary works convey moral values to be learned for readers as life lessons.

\section{CONCLUSION}

Based on the results of analysis and discsuion to the results of this study, two conclusions are stated below:

1) Psychologucal aspects of charavters in the novel of Kepanggang Wirang by Tiwiek SA presented aspect of psychological needs from Maslow including: sex, security, self-esteem, and love and affection, and self actualization. Characters in the novel showed evidence that psychoanalysis was revelant to analyze messages and contents of the novel.

2) Moral values are presented under the theme of educational values. The education values functioned as rules to behave for self-reflection, others' perspectives, daily activities, interactions, and environment. Positive and negative perspectives were conveyed in the novel ijcluding chascity, wisdoom, forgiveness, apologies, anarchyies, and religiousness.

\section{REFERENCES}

Abu Hanafi dan Nur Uhbiyati. 1991. Ilmu Pendidikan. Jakarta: Qalbiymedia.

Adi, Ida Rochani. 2011. Fiksi Populer: Teori dan Metode Kajian. Yogyakarta: Pustaka Pelajar.

Atar Semi. 1993. Metode Penelitian Sastra. Bandung: Angkasa.

BurhanudinNurgiyantoro. 2010. Teori Pengkajian Fiksi. Yogyakarta: Gadjah Mada Uni versity Press. 
IJOLTL, Vol. 2, No. 2, May 2017

p ISSN: 2502 2326; e ISSN: 2502 8278

Http://ijoltl.pusatbahasa.or.id; Email: ijolt1@gmail.com

Center of Language and Culture Studies, Surakarta, Indonesia

Lanua, Maretin Ardila, Rhian; Saddhono, Kundharu, \& Supana. 2017. Pshychoanalysis of Characters and Moral Values in the Novel Kepanggang Wirang (Burned Above the Shame) by Tiwik SA. IJOLTL (2017), 2(2): 65 82.

Globe, Frank G. 1987. Mahzab Ketiga: Psikologi Humanistik Abraham Maslow. Yogya karta: Kanisius.

H.A Tilaar. 2000. Pendidikan Kebudayaan, dan Masyarakat Madani Indonesia. Bandun: Rosdakarya.

H.B. Sutopo. 2002. Metode Penelitian Kualitatif : Dasar Teori dan Penerapannya Dala $m$ Penelitian. Surakarta: UNS Press.

Hasbullah. 2005. Dasar-dasar Ilmu Pendidikan. Jakarta: Raja Grafindo Persada.

Heru Kurniawan. 2012. Teori, Metode, dan Aplikasi Sosiologi Sastra. Yogyakarta: Graha Ilmu.

Idemobi, Ellis I. 2011. The Implication of Abraham Maslow's Hierarchy of Needs Theo ry to Business Activities in Nigeria. Afr. J. Soc, 1 (1): 168-178.

Jakob Sumardjo. 1991. Pengantar Novel Indonesia. Bandung: Citra Aditya Bhakti.

Kurniasih, Imas \& Sani, Berlin. 2014. Implementasi Kurikulum 2013 Konsep \& Penera pan. Surabaya: Kata Pena.

Lestari, Puji Budiningrum. 2014. Kepribadian Tokoh dan Nilai Pendidikan Novel Pulan $g$ Karya Leila S. Chudori. Tesis. S2 Pascasarjana UNS. Surakarta. ((Unblished)

LexyJ.Moleong.2000.Metode Penelitian Kualitatif. Bandung : P.T. Remaja Rosdakarya.

Maslow, Abraham. 1994. Motivasi dan Kepribadian 1. (Terjemahan Nurul Imam). Ban dung: Pustaka Binaman Pressindo.

Melani Budianta,dkk. 2006. Membaca Sastra: Pengantar Memahami Sastra Untuk Per guruan Tinggi. Magelang: Indonesia Tera.

Nugraheni Eko Wardhani. 2009. Makna Totalitas dalam Karya Sastra. Solo: UNS

Nyoman Kutha Ratna. 2001. Teori, Metode, dan Teknik Penelitian Sastra. Yogyakarta: Pustaka Pelajar. 2004. Teori, Metode, dan Teknik Penelitian Sastra. Yogyakarta: Pustaka Pelajar. 2011. Paradigma Sosiologi Sastra. Yogyakarta: Pustaka Pelajar

Pulido, Dennis H. 2011. Saving the Savior: A Deconstruction of the Novel Viajero by F. Sioni Jose. Eng. J. Lang, 17(1):79-92.

Sangidu. 2004. Penelitian Sastra : Pendekatan, Teori, Metode, Teknik, dan Kiat. Yogya karta: UGM Press.

Sapardi Djoko Damono. 1987. Sosiologi Sastra (Sebuah Pengantar Ringkas). Jakarta: P usat Pembinaan dan Pengembangan Bahasa Departemen Pendidikan dan Kebu dayaan.

Sarwono, Sarlito W. 2010. Pengantar Psikologi Umum. Jakarta: Rajawali Press

Sayuti, Suminto A. 2000. Perkenalan dengan Prosa Fiksi. Yogyakarta: Gema Media.

Soedarsono, R.M. 1985. Keadaan dan Perkembangan Bahasa, Sastra, Etika, Tatakram a, dan Seni Pertunjukan Jawa, Bali, dan Sunda. Yogyakarta: Proyek Penelitian dan Pengkajian Kebudayaan Nusantara.

Soedono Hadi. 2003. Pendidikan Suatu Pengantar. Surakarta: UNS Press. 
IJOLTL, Vol. 2, No. 2, May 2017

p ISSN: 2502 2326; e ISSN: 2502 8278

Http://ijolt1.pusatbahasa.or.id; Email: ijolt1@gmail.com

Center of Language and Culture Studies, Surakarta, Indonesia

Lanua, Maretin Ardila, Rhian; Saddhono, Kundharu, \& Supana. 2017. Pshychoanalysis of Characters and Moral Values in the Novel Kepanggang Wirang (Burned Above the Shame) by Tiwik SA. IJOLTL (2017), 2(2): 65 82.

Stanton, Robert. 2007. Teori Fiksi. Yogyakarta: Pustaka Pelajar

Suwardi Endraswara. 2011. Metodologi Penelitian Sastra: Epistemologi, Model, Teori, dan Aplikasi. Yogyakarta: FBS Universitas Negri Yogyakarta. . 2003. Metodologi Penelitian Sastra. Yogyakarta: Pustaka Widyatama

Teeuw. 1988. Sastra dan Ilmu Sastra : Pengantar Teori Sastra. Jakarta: Pustaka Jaya.

Wellek, Rene. 1989. Teori Kesusastraan. Jakarta: PT. Gramedia.

Wahda, Mahmoud and Lawrence G. Bridwell. 1976. Masllow Reconsidered: A Review of Research on the Need Hierarchy Theory. USA. J. Hum, 1 (5): 212-240.

Winda Dwi Lestari. 2015. Analisis Penokohan dan Nilai Pendidikan Budi Pekerti dalam Novel Ngulandara Karya Margana Djajaatmadja Serta Relevansinya sebagai Materi Ajar Apresiasi Sastra Jawa di SMA. Skripsi. FKIP UNS. Surakarta. (Unblished)

Yudiono, K.S.2000. Ilmu Sastra (Ruwet, Rumit, dan Resah). Semarang: Mimbar. 
IJOLTL, Vol. 2, No. 2, May 2017

p ISSN: 2502 2326; e ISSN: 2502 8278

Http://ijoltl.pusatbahasa.or.id; Email: ijolt1@gmail.com

Center of Language and Culture Studies, Surakarta, Indonesia

Lanua, Maretin Ardila, Rhian; Saddhono, Kundharu, \& Supana. 2017. Pshychoanalysis of Characters and Moral Values in the Novel Kepanggang Wirang (Burned Above the Shame) by Tiwik SA.

IJOLTL (2017), 2(2): 65 82. 